\title{
Efikasi Diri Dan Sikap Pada Intensi Berwirausaha (Studi pada Mahasiswa Program Studi Manajemen Fakultas Ekonomi Universitas Muhammadiyah Purworejo)
}

\author{
Ridwan Baraba ${ }^{1}$ \\ Universitas Muhammadiyah Purworejo \\ barabaridwan@gmail.com
}

\begin{abstract}
Abstrak: Kondisi perekonomian yang kian tidak menentu berdampak pada ketersediaan lapangan pekerjaan baik sector formal ataupun informal semakin berkurang disisi lain angkatan kerja semakin pesat pula pertumbuhannya hal ini menuntut dibukanya lebih luas lagi lapangan pekerjaan yang ada secara mandiri dalam bentuk kegiatan wirausaha. Generasi muda diantaranya mahasiswa memiliki beban untuk merencanakan berwirausaha sejak dini. Minat berwirausaha harus ditumbuh kembangkan sejak dini agar kedepan lebih siap membuka suatu usaha baru. Banyak hal yang bisa menjadi pengaruh menumbuhkan minat berwirausaha pada diri mahasiswa diantaranya sikap dan efikasi diri. Penelitian ini bertujuan melihat pengaruh efikasi diri dan sikap terhadap intensi berwirausaha pada mahasiswa Program studi Manajemen Fakultas Ekonomi Universitas Muhammadiyah Purworejo. Populasi dalam penelitian ini adalah seluruh mahasiswa semester V tahun akademik 2020/2021 yang telah menempuh matakuliah Entrepreneurship and Business Planning sebanyak 169 orang, jumlah sampel yang diambil yaitu 120 responden berdasarkan rumus slovin.. Pengumpulan data dalam penelitian ini dilakukan dengan menggunakan tekhnik purposive sampling. Pengumpulan data menggunakan kuesioner dengan alternatif pilihan jawaban menggunakan skala Likert yang terdiri dari lima pilihan jawaban. Kuesioner telah diuji cobakan dan telah memenuhi syarat validitas dan reliabilitas. Pengujian hipotesis dilakukan dengan regresi linier berganda menggunakan program SPSS 25.0. Berdasarkan hasil analisis disimpulkan Efikasi diri secara parsial berpengaruh positif terhadap intensitas berwirausaha meskipun tidak signifikan begitu juga Sikap secara parsial berpengaruh positif dan signifikan terhadap Intensi Berwirausaha.
\end{abstract}

Kata kunci: Efikasi Diri, Sikap, Intensi Berwirausaha.

Pembangunan sumber daya manusia merupakan hal yang mutlak dilakukan karena sumber daya manusia merupakan motor penggerak bagi sumberdaya yang lainnya, Bahkan pemerintahan Presiden Joko Widodo di putaran yang ke dua dari lima hal yang menjadi target pemerintahannya di target yang pertama beliau menyatakan pembangunan Sumber Daya Manusia (SDM) menjadi prioritas utamanya. Menurutnya membangun SDM yang bermental pekerja keras yang dinamis amatlah penting. Pembangunan Nasional pada hakekatnya adalah pembangunan manusia Indonesia seutuhnya dan pembangunan yang ditujukan untuk seluruh bangsa Indonesia. Oleh karena itu, kunci dari pembangunan manusia seutuhnya adalah memajukan sumber daya manusia yang ada dalam mengelola dan mengupayakan sumber daya alam yang tersedia. Pembangunan manusia Indonesia seutuhnya harus dibarengi dengan sikap dan nilai perilaku manusia itu sendiri. Sebagaimana kita pahami mahasiswa merupakan sumber daya manusia yang merupakan penerus bangsa sebagai penentu masa depan bangsa karena ditempa dalam keintelektualannya berpikir dan bertindak demi masa depan bangsa. 
Menurut Badan Pusat Statistik Nasional, jumlah Angkatan Kerja di Indonesia 2019 sebanyak 133,560 juta orang, naik 2,55 juta orang dibanding 2018. Dari 133,560 juta orang total Angkatan Kerja, sebanyak 7,045 juta orang penduduk masih mencari pekerjaan (pengangguran). Meskipun jumlah tersebut mengalami penurunan 45 ribu orang dibanding 2018. Berdasarkan Data BPS pada Provinsi Jawa Tengah menunjukan, jumlah penganggur pada 2018 di Jawa Tengah sebanyak 814.345 orang. Mangalami peningkatan sebanyak 5,010 orang dibanding 2019 sebanyak 819,355 orang. Hal ini terjadi karena jumlah lapangan pekerjaan yang tersedia tidak sebanding dengan jumlah lulusan universitas yang bergelar sarjana. Peningkatan jumlah penganggur justru semakin didominasi oleh penganggur yang terdidik. Hal ini mengindikasikan bahwa lulusan Perguruan Tinggi adalah lebih sebagai pencari kerja (job seeker) daripada pencipta lapangan pekerjaan (job creator) (Sumarsono,2013). Berdasarkan fenomena diatas perguruan tinggi memiliki peranan besar mempersiapkan lulusannya untuk mempersiapkan atau membuka lapangan pekerjaan sendiri. Upaya yang dilakukan perguruan tinggi tentunya dengan membekali calon lulusannya pengetahuan terkait dengan kewirausahaan. Diawali dengan Visi, tujuan perguruan tinggi tersebut lalu dijabarkan dalam kurikulum yang ada serta diberikannya pelatihan pelatihan atau magang pada pelaku usaha yang ada sehingga meningkatkan pengetahuan tentang kewirausahaan. Pengaruh pendidikan kewirausahaan selama ini telah dipertimbangkan sebagai salah satu faktor penting untuk menumbuhkan dan mengembangkan hasrat, jiwa dan perilaku berwirausaha di kalangan generasi muda (Kourilsky dan Walstad, 1998).

Beberapa penelitian sebelumnya menyebutkan bahwa keinginan berwirausaha para mahasiswa merupakan sumber bagi lahirnya wirausaha-wirausaha masa depan (Kourilsky dan Walstad, 1998). Sikap, perilaku dan pengetahuan mereka tentang kewirausahaan akan membentuk kecenderungan mereka untuk membuka usaha-usaha baru di masa mendatang.

Mahasiswa Programstudi Manajemen Fakultas Ekonomi Universitas Muhammadiyah Purworejo yang menekuni ilmu manajerial, teori dan praktek ilmu ekonomi khususnya kewirausahaan, diharapkan memiliki jiwa wirausaha yang tinggi, sehingga nantinya akan mampu membuka lapangan pekerjaan yang lebih luas. Dengan kemampuan yang mereka miliki ini akan mengurangi ketergantungannya pada persaingan dalam memperebutkan lapangan pekerjaan yang terbatas. Disisi lain di era sekarang ini pemerintah mengefisienkan birokrasi yang ada sehingga berdampak pada semakin sedikitnya kesempatan bekerja pada pemerintahan. Untuk itu perguruan tinggi sebagai lembaga yang menjadi salah satu panutan masyarakat dapat mendorong budaya berwirausaha. Perguruan tinggi diharapkan juga mampu menciptakan wirausahawanwirausahawan yang handal, sehingga mampu memberi dorongan minat bagi mahasiswa untuk berwirausaha. Mahasiswa sebagai komponen 
masyarakat yang terdidik, sebagai harapan masyarakat untuk dapat membuka lapangan pekerjaan dengan menumbuhkan minat berwirausaha.

Berdasarkan Theory of Planned Behavior (TPB) (Ajzen dalam Dharmmesta, 1998) bahwa sebuah perilaku dengan keterlibatan tinggi membutuhkan keyakinan dan evaluasi untuk menumbuhkan sikap, norma subyektif, dan kontrol keperilakuan dengan intensi sebagai mediator pengaruh berbagai faktorfaktor motivasional yang berdampak pada suatu perilaku. Keputusan berwirausaha merupakan perilaku dengan keterlibatan tinggi (high involvement) karena dalam mengambil keputusan akan melibatkan faktor internal seperti kepribadian, persepsi, motivasi, pembelajaran (sikap), faktor eksternal seperti keluarga, teman, tetangga dan lain sebagainya (norma subyektif). Kemudian mengukur kontrol keperilakuan yang dirasakan (efikasi diri) yaitu suatu kondisi bahwa orang percaya tindakan itu mudah atau sulit untuk dilakukan dengan memahami berbagai risiko atau rintanganrintangan yang ada apabila mengambil tindakan tersebut (Ajzen, 2008).

Bandura (1977: 2) mendefinisikan efikasi diri sebagai kepercayaan seseorang atas kemampuan dirinya untuk menyelesaikan suatu pekerjaan. Atau dengan kata lain, kondisi motivasi seseorang yang lebih didasarkan pada apa yang mereka percaya dari pada apa yang secara objektif benar. Persepsi pribadi seperti ini memegang peranan penting dalam pengembangan intensi seseorang. Efikasi diri yaitu kepercayaan (persepsi) individu mengenai kemampuan untuk membentuk suatu perilaku berwirausaha. Efikasi diri diukur dengan skala (Gadaam, 2008) dengan indikator kepercayaan diri akan kemampuan mengelola usaha, kepemimpinan sumber daya manusia, kematangan mental dalam usaha, dan merasa mampu memulai usaha.

Sikap dimaknai sebagai kecenderungan untuk bereaksi secara afektif dalam menanggapi risiko yang akan dihadapi di dalam bisnis (Gadaam,2008). Garbuz dan Aykol (2008) menemukan beberapa unsur sikap yang berpengarug pada niat kewirausahaan mahasiswa yaitu authonomy, economic challenge, self realization, perceived confidence security \& workload, avoid responsibility, dan social career. Menurut Priyanto (2008), sikap merupakan salah satu faktor internal yang mempengaruhi pembentukan jiwa kewirausahaan selain faktor internal yang lain yaitu sifat-sifat personal, kemauan dan kemampuan individu. Dari uraian tersebut makan dapat sikap merupakan kecenderungan seseorang untuk merespon keinginan dari dalam diri yang dipengaruhi oleh objek-objek disekitar (Sumadi dan Sulistyawati, 2017).

Menurut Wijaya (2007) intensi adalah kesungguhan niat seseorang untuk melakukan perbuatan atau memunculkan suatu perilaku tertentu. Intensi kewirausahaan dapat diartikan sebagai proses pencarian informasi yang dapat digunakan untuk mencapai tujuan pembentukan suatu usaha (Katz dan Gartner, 1988). Sedangkan Menurut Yanto (1996: 23-24) intensi wirausaha adalah kemampuan untuk memberanikan diri 
dalam memenuhi kebutuhan hidup serta memecahkan permasalahan hidup, memajukan usaha atau menciptakan usaha baru dengan kekuatan yang ada pada diri sendiri. Intensi wirausaha adalah gejala psikis untuk memusatkan perhatian dan berbuat sesuatu terhadap wirausaha itu dengan perasaan senang karena membawa manfaat bagi dirinya (Santoso,1993: 19). Intensi berwirausaha yaitu tendensi keinginan individu untuk melakukan tindakan wirausaha dengan menciptakan produk baru melalui peluang bisnis dan pengambilan risiko. Intensi berwirausaha diukur dengan skala entrepreneurial intention (Ramayah \& Harun, 2005) dengan indikator memilih jalur usaha dari pada bekerja pada orang lain, memilih karir sebagai wirausahawan, membuat perencanaan untuk memulai usaha, meningkatkan status sosial (harga diri) sebagai wirausaha dan mendapatkan pendapatan yang lebih baik.

Beberapa penelitian telah dilakukan mengenai variabel-variabel yang mempengaruhi intensi berwirausaha. Andika dan Madjid (2012) menemukan bahwa variabel sikap dan efikasi diri secara parsial berpengaruh signifikan terhadap intensi berwirausaha pada mahasiswa Fakultas Ekonomi Unsyiah, sedangkan variabel norma subyektif secara parsial tidak berpengaruh signifikan terhadap intensi berwirausaha pada mahasiswa Fakultas Ekonomi Unsyiah. Sedangkan penelitian yang dilakukan penelitian Pormes dan Sipakoly (2019) yang menunjukkan bahwa terdapat hubungan yang signifikan antara sikap dengan intensi berwirausaha secara parsial.

Tujuan dari artikel ini dari hasil penelitian yang dilakukan untuk mengetahui pengaruh efikasi diri dan sikap mahasiswa Programstudi Manajemen Fakultas Ekonomi Universitas Muhammadiyah Purworejo terhadap intensi mereka untuk berwirausaha.

\section{METODE}

\section{Variabel dan Definisi Operasional}

Penelitian ini menggunakan dua variabel independen dan satu variabel dependen. Variabel independen dalam penelitian ini adalah: Efilasi Diri (X1) dan Sikap (X2) sedangkan variabel dependennya adalah Intensi Berwirausaha $(Y)$. Berikut definisi operasional dari masing - masing variabel seperti dalam tabel 1 berikut.

Tabel 1.

Definisi Operasional Variabel

\begin{tabular}{ll}
\hline Variabel & \multicolumn{1}{c}{ Definisi Operasional } \\
\hline Intensi Berwirausaha (Y) & $\begin{array}{l}\text { Tendensi keinginan individu melakukan } \\
\text { tindakan wirausaha dengan menciptakan } \\
\text { produk baru melalui peluang bisnis dan } \\
\text { pengambilan risiko (Ramayah \& Harun } \\
\text { 2005) } \\
\text { Kepercayaan (persepsi) individu mengenai } \\
\text { kemampuan untuk membentuk suatu }\end{array}$ \\
\hline
\end{tabular}


Sikap (X2)

perilaku berwirausaha (Gadaam, 2008)

Kecenderungan untuk bereaksi secara afektif dalam menanggapi risiko yang akan dihadapi di dalam bisnis (Gadaam,2008)

\section{Data dan Metode Pengumpulan}

Data yang digunakan dalam penelitian ini adalah data primer. Data primer yang digunakan adalah data yang berasal dari responden secara langsung. Metode yang digunakan untuk mengambil data primer pada penelitian ini adalah menggunakan kuesioner. Jenis skala yang digunakan adalah skala Likert dengan lima pilihan jawaban yaitu sangat setuju (SS), setuju (S), kurang setuju (KS), tidak setuju (TS), sangat tidak setuju (STS). Nilai dari masing-masing pilihan jawaban berkisar dari 1 hingga 5. Kualitas kuesioner di ukur dengan menggunakan uji validitas dan reliabilitas. Uji validitas dilakukan dengan validitas konstruk yaitu dengan mengkorelasikan skor item tiap pernyataan dengan skor total. Uji reliabilitas dilakukan dengan coefficient cronbach's alpha.

\section{Populasi dan Sampel}

Populasi dalam penelitian ini adalah mahasiswa Programstudi Manajemen Fakultas Ekonomi Universitas Muhammadiyah Purworejo semester V tahun akademik 2020/2021 yang sudah menempuh mata kuliah Entrepreneurship and Business Planning dengan jumlah 169 orang. Sampel yang diambil dari populasi yang ada dilakukan secara simple random sampling (acak), (Sugiyono, 2007). Sampel dalam penelitian ini berjumlah 120 orang diperoleh dengan menggunakan rumus Slovin dengan menggunakan tingkat kesalahan 5. Prinsip pemilihan sampel dalam desain ini adalah setiap elemen dalam populasi mempunyai kesempatan yang sama untuk dipilih (Kuncoro, 2003).

\section{Metode Analisis}

Metode analisis data yang digunakan dalam penelitian ini adalah analisis regresi linear berganda. Sebelum dilakukan analisis regresi berganda. Data akan dianalisis menggunakan program SPSS Statistik 25. Model ini dipilih untuk mengukur besarnya pengaruh variabel bebas terhadap variabel terikat. Dengan persamaan regresi sebagai berikut:

$$
\begin{array}{ll}
\mathrm{Y}=\mathrm{a}+\mathrm{b} 1 \mathrm{X} 1+\mathrm{b} 2 \mathrm{X} 2+\mathrm{e} \\
\text { Keterangan: } \\
\mathrm{Y} & : \text { Variabel Intensi Berwirausaha } \\
\mathrm{X} 1 & : \text { Variabel Efikasi Diri } \\
\mathrm{X} 2 & \text { : Variabel Sikap } \\
\mathrm{b} 1, \mathrm{~b} 2 & : \text { Koefisien beta variabel X1 dan X2. } \\
\mathrm{e} & : \text { Eror term }
\end{array}
$$




\section{HASIL}

1. Hasil Uji Validitas dan Reliabilitas

Hasil uji validitas dan reliabilitas dalam penelitian adalah semua variable penelitian dinyatakan valid karena memiliki nilai $r$ hitung di atas 0,05 dan reliabel karena memiliki nilai Cronbach alfa diatas 0,06.

\section{Deskripsi Responden}

Berikut ini adalah tabel deskripsi responden berdasarkan usia, jenis kelamin, dan Pekerjaan Orang Tua:

Tabel 2.

Deskripsi Data Responden Berdasarkan Usia

\begin{tabular}{ccc}
\hline Interval & Jumlah Responden & Persentase (\%) \\
\hline $20-22$ & 84 & 70 \\
$23-25$ & 24 & 20 \\
$>25$ & 12 & 10 \\
Total & 120 & 100 \\
\hline
\end{tabular}

Sumber: Data Primer (2021).

Tabel 3.

Deskripsi Data Responden Berdasarkan Jenis Kelamin

\begin{tabular}{ccc}
\hline Jenis Kelamin & Jumlah Responden & Persentase (\%) \\
\hline Laki - Laki & 29 & 24 \\
Perempuan & 91 & 76 \\
Total & $\mathbf{1 2 0}$ & $\mathbf{1 0 0}$ \\
\hline
\end{tabular}

Sumber: Data Primer (2021).

Tabel 4.

Deskripsi Data Responden Berdasarkan Pekerjaan Orang Tua

\begin{tabular}{ccc}
\hline Jenis Pekerjaan & Jumlah Responden & Persentase (\%) \\
\hline Aparatur Sipil Negara (ASN) & 14 & 11,6 \\
TNI / POLRi & 2 & 1,67 \\
Wiraswasta & 72 & 60 \\
Karyawan Swasta & 24 & 20 \\
Pensiunan & 8 & 6,66 \\
Total & 120 & 100 \\
\hline
\end{tabular}


Sumber: Data Primer (2021).

Berdasarkan tabel 2 dapat diketahui bahwa responden dengan rentang usia 20 - 22 tahun merupakan responden dengan jumlah terbanyak yaitu sebanyak 84 orang atau sebesar $70 \%$ dari keseluruhan responden. Sedangkan responden dengan rentang usia 23 - 25 tahun menempati urutan kedua dengan jumlah 24 orang atau sebesar $20 \%$ dari keseluruhan populasi. Responden dengan rentang usia $>25$ tahun berjumlah 12 orang atau sebesar $10 \%$.

Adapun berdasarkan tabel 3 dapat diketahui bahwa responden perempuan mendominasi responden dengan jumlah 91 orang atau $76 \%$ sedangkan responden laki - laki sebanyak 29 orang atau sebanyak $24 \%$.

Tabel 4 memberikan informasi data responden berdasarkan pekerjaan orang tuanya, Wiraswata mendominasi jenis pekerjaan orang tua dari responden sebanyak 72 orang atau sebanyak $60 \%$, disusul pekerjaan orang tua responden sebagai karyawan swasta 24 orang atau sebanyak $20 \%$. Sedangkan pekerjaan orang tua ASN ada 14 orang atau sebanyak $11,6 \%$, pekerjaan orang tua pensiunan ada 8 orang atau sebanyak $6,66 \%$ dan pekerjaan orang tua sebagai TNI / POLRI merupakan jumlah yang paling rendah yaitu 2 orang atau sebanyak $1,67 \%$.

3. Hasil Analisis Regresi Linier Berganda

Untuk mengetahui pengaruh dari variabel independen efikasi diri (X1), dan sikap (X2) terhadap variabel dependen intensi berwirausaha $(Y)$ maka digunakan model analisis linier berganda. Adapun pengaruh masing-masing variabel independen terhadap variabel dependen secara rinci dapat dilihat pada tabel 5 di bawah ini sebagai berikut:

Tabel 5

Analisis Regresi Berganda

\begin{tabular}{cccc}
\hline $\begin{array}{c}\text { Variable } \\
\text { Independent }\end{array}$ & $\begin{array}{c}\text { Standardized } \\
\text { Koefisien Beta }\end{array}$ & t Hitung & Signifikansi \\
\hline Konstanta & - & - & \\
Efikasi Diri &, 048 &, 503 &, 616 \\
Sikap &, 544 & 5,665 &, 000 \\
$\mathbf{R}^{2}$ & &, 331 & \\
F hitung & & 28,995 & \\
Variable & & Intensi Berwirausaha & \\
Dependent & & & \\
\hline
\end{tabular}

Sumber Data: Diolah (2021)

Berdasarkan hasil uji statistik regresi linier berganda yang dianalisis dengan pengolahan data SPSS versi 25.0 seperti yang terlihat pada tabel diatas, maka diperoleh persamaan regresi sebagai berikut: $Y=0,048 X 1+0,544 X 2$. Dari kedua nilai koefisien pada variabel-variabel independen di atas diperoleh bahwa Variabel efikasi diri dan sikap memberikan pengaruh yang positif terhadap variabel 
intensi berwirausaha, variabel sikap memiliki nilai koefisien terbesar dengan nilai koefisien 0,544 , sedangkan nilai koefisien efikasi diri adalah sebesar 0,048. Berdasarkan hasil tersebut diperoleh bahwa variabel sikap merupakan faktor yang paling dominan yang mempengaruhi intensi berwirausaha. Hasil analisis menunjukan bahwa secara partial variabel efikasi diri (X1) tidak berpengaruh secara signifikan terhadap intensi berwirausaha $(Y)$ yang ditunjukan dengan $p$ value $>$ a yaitu $0,616>0,05$. Sedangkan variabel sikap (X2) secara partial berpengaruh secara signifikan terhadap intensi berwirausaha (Y) yang ditunjukan dengan $p$ value $<\alpha$ yaitu $0,000<0,05$.

Berdasarkan tabel 5 diatas Derajat keeratan hubungan antara kedua variabel independen (efikasi diri dan sikap) dengan intensi berwirausaha mahasiswa Fakultas Ekonomi Universitas Muhammadiyah Purworejo termasuk kategori kuat, ditunjukkan oleh nilai koefisien korelasi $(R)$ sebesar 0,575 . Nilai koefisien determinasi $\left(R^{2}\right)$ sebesar 0,331 yang menandakan bahwa sebesar $33 \%$ intensi berwirausaha mahasiswa Fakultas Ekonomi Universitas Muhammadiyah Purworejo dipengaruhi / dijelaskan oleh variabelvariabel, efikasi diri dan sikap sedangkan sisanya sebesar $77 \%$ dipengaruhi oleh faktor-faktor lain yang tidak teramati.

\section{Pengaruh Efikasi Diri terhadap Intensi Berwirausaha}

Hasil analisis menunjukan bahwa tidak terdapat pengaruh yang signifikan secara partial antara efikasi diri terhadap intensi berwirausaha yang ditunjukan dengan nilai $p$ value 0,616 yang lebih besar dari sebesar nilai a 0,05. Namun variabel efikasi diri memberikan pengaruh yang positif terhadap intensi berwirausaha. Efikasi diri merupakan kepercayaan (persepsi) yang dimiliki individu mengenai kemampuan - kemapuan yang mereka miliki untuk membentuk suatu perilaku berwirausaha. Sehingga, mahasiswa hendaknya memiliki keyakinan dalam dirinya bahwa dia mampu untuk menjalankan suatu usaha kemampuan yang mereka miliki dilandasi dari pengetahuan yang mereka peroleh dalam perkuliahan seperti telah ditempuhnya mata kuliah Entrepreneurship and Business Planning dan matakuliah lain yang bisa mendukung keyakinan mahasiswa dalam berwirausaha, Masa pandemic Covid 19 bisa jadi menjadi penyebab kurangnya rasa percaya diri tersebut karena mahasiswa melihat ketidak pastian perekonomian yang ada sehingga dianggap akan mempengaruhi keinginan mahasiswa untuk berwirahusaha. Kondisi semacam ini dimungkinkan akan menurunkan kepercayaan diri mengelola usaha, kepemimpinan sumber daya manusia, faktor usia yang masih muda bisa jadi penyebab belum matangannya mental dalam memulai usaha, kurang teguhnya keyakinan dalam memulai usaha, serta kemampuan memulai usaha yang kurang terasah. 


\section{Pengaruh Sikap terhadap Intensi Berwirausaha}

Hasil analisis menunjukan bahwa secara partial sikap memiliki pengaruh yang signifikan terhadap intensi berwirausaha yang ditunjukan dari $p$ - value sebersar 0,000 yang lebih kecil dari nilai $\alpha$ sebesar 0,05 . Sikap merupakan kecenderungan untuk bereaksi secara afektif dalam menanggapi risiko yang akan dihadapi di dalam bisnis. Hasil ini menunjukkan adanya ketertarikan mahasiswa dengan peluang usaha. Mereka juga berfikir kreatif dan inovatif, memiliki pandangan positif terhadap kegagalan yang dianggap sebagai awal keberhasilan, dimilikinya jiwa kepemimpinan dan tanggung jawab. Suka menghadapi risiko dan tantangan. Hal ini didukung oleh penelitian yang dilakukan oleh Andika dan Madjid (2012) yang menunjukan bahwa terdapat hubungan yang signifikan antara sikap dengan intensi berwirausaha dengan nilai $p-$ value sebesar 0,001 yang lebih kecil dari nilai $\alpha 0,05$. Semakin tinggi sikap yang dimiliki mahasiswa maka semakin tinggi pula intensi dalam berwirausaha. Hasil penelitian Pormes dan Sipakoly (2019) yang menunjukan bahwa terdapat hubungan yang signifikan antara sikap dengan intensi berwirausaha dengan nilai $p$-value sebesar 0,04 yang lebih kecil dari nilai a 0,05. Semakin baik sikap yang dimiliki mahasiswa maka semakin tinggi pula intensi dalam berwirausaha.

\section{KESIMPULAN}

Berdasarkan hasil analisis data dan pembahasan, dapat ditarik kesimpulan sebagai berikut :

1 Efikasi diri secara partial berpengaruh namun tidak signifikan terhadap intensi berwirahusaha.

2 Sikap secara partial berpengaruh yang signifikan terhadap intensi berwirausaha.

\section{DAFTAR PUSTAKA}

Ajzen, I., (2008). Attitudes and Attitude Change. Psychology Press: WD Cranoeds

Bandura, A., (1977). Social Learning Theory, Englewood Cliffs, New Jersey: Prentice Hall.

Dharmmesta, B.S. (1998), Teory Of Planned Behavior Dalam Penelitian Sikap, Niat dan Perilaku Konsumen, Jurnal Kelola. No. 18/VII/1998.

Gaddam, Soumya., (2008). Identifying the Relayionship Between Behavioral Motives and Entrepreneurial Intentions: An Empirical Study Based Participations of Business Management Students. The Icfaian Journal of Management Research. Vol.7,pp. 35-5.

Gurbuz, G. \& Aykol, S. (2008), Entrepreneurial Intentions of Young Educated Public in Turkey. Journal of Global Strategic Management, 4(1): 47-56.

Katz, J., dan W. Gartner, (1988). Properties of emerging organizations. Journal of Academy of Management Review. Vol. 13 (3) pp. 429-441. 
Kourilsky, M. L. dan W. B. Walstad, (1998). Entrepreneurship and female youth: knowledge, attitude, gender differences, and educational practices. Journal of Business Venturing. Vol. 13 (1) pp. 77-88.

Kuncoro, M. (2003). Metode riset untuk bisnis \& ekonomi. Jakarta: Erlangga.

Manda Andika dan Iskandarsyah Madjid. (2012). Analisis Pengaruh Sikap, Norma Subyektif Dan Efikasi Diri Terhadap Intensi Berwirausaha Pada Mahasiswafakultas Ekonomi Universitas Syiah Kuala (Studi Pada Mahasiswa Fakutas Ekonomi Universitas Syiah Kuala). EcoEntrepreneurship Seminar \& Call for Paper "Improving Performance by Improving Environment" 2012 Fakultas Ekonomi, Universitas Negeri Semarang.

Pormes, Ludwina dan Sipakoly, Selly. (2019). Pengaruh Sikap dan Motivasi terhadap Niat Berwirausaha (Studi pada Mahasiswa Jurusan Akuntansi Politeknik Negeri Ambon). JURNAL MANEKSI VOL 8, NO. 2, Desember 2019204 p-ISSN: 2302-9560 /e-ISSN: 2597-4599.

Priyanto, (2008), Farmakoterapi Dasar untuk Mahasiswa Keperawatan dan Farmasi, Leskonfi, Jakarta.

Ramayah, T., \& Harun, Z., (2005). Entrepreneurial Intention Among the Studen of Universiti Sains Malaysia (USM). International Journalof Management and Entrepreneurship, Vol. 1 pp. 8-20.

Santoso. (1993).. Lingkungan Tempat Tinggal dalam Menentukan Minat Berwiraswasta FKIP UNS. (Laporan Penelitian). Surakarta: UNS.

Sugiyono (2007). Metode penelitian pendidikan, pendekatan kuantitatif, kualitatif, dan $R \& D$. Ban-dung: Alfabeta.

Sumarsono, (2013). Faktor-faktor yang mempengaruhi intense wirausaha. Jurnal Ekuilibrium Vol.11 No.2.

Sumadi,Agus dan Sulistyawati, Eka. (2017). Pengaruh sikap, motivasi dan lingkungan terhadap niat berusaha. E-jurnal manajemen Unud, Vol 6 No 2

Wijaya, Tony, (2008). Kajian Model Empiris Berwirausaha UKM DIY dan Jawa Tengah. Jurnal Manajemen dan Kewirausahaan.

Yanto. (1996). Peluang Kerja dan Minat Berwiraswasta di Kalangan Siswa Sekolah Teknologi Menengah Negeri Pembangunan Pekalongan (Laporan Penelitian). Semarang: IKIP Semarang.

Sumber Lain:

BPS. (2019). Statistik Indonesia. Tersedia di www.bps.co.id. Diakses pada 11 Januari 2021.

BPS. (2020). Statistik Indonesia. Tersedia di www.bps.co.id. Diakses pada 11 Januari 2021. 